\title{
Cutleaf Evening Primrose and Palmer Amaranth Reduce Growth of Nonbearing Pecan Trees
}

\author{
Margaret E. Wolf and Michael W. Smith \\ Department of Horticulture and Landscape Architecture, Oklahoma State \\ University, Stillwater, OK 74078
}

Additional index words. Carya illinoinensis, Amaranthus palmeri, Oenothera laciniata,
weed competition, weed interference

\begin{abstract}
Growth of 'Apache' pecan [Carya illinoinensis (Wangenh.) K. Koch] seedlings was evaluated for 3 years when grown in a $11.2-\mathrm{m}^{2}$ weed-free area or when various combinations of one or two plants of cutleaf evening primrose (Oenothera laciniata Hill), a cool-season species, or Palmer amaranth (Amaranthus palmeri S. Wats.), a warm-season species, were grown $30 \mathrm{~cm}$ from the tree, with the rest of the $11.2-\mathrm{m}^{2}$ area weed-free. Either weed species alone suppressed tree growth compared to the weed-free control. A temporal succession of primrose followed by amaranth reduced growth most. After 3 years, two plants of primrose followed in succession by two of amaranth caused a $79 \%$ reduction in cumulative current-season's growth.
\end{abstract}

Vegetation surrounding young pecan trees is detrimental to growth (Foshee et al., 1995; Norton and Storey, 1970; Patterson and Goff, 1994; Patterson et al., 1990) and in some cases reduces tree survival. Weed competition can dramatically reduce yield of young, bearing trees (Foshee et al., 1997). Yield of mature pecan trees is also reduced by competing vegetation (Hunter, 1950). Certain herbicides can be used to eliminate vegetative groundcover that is in close proximity to the tree without tree injury (Aitken, 1974; Arnold and Aldrich, 1979). However, herbicides with postemergent activity rarely eliminate all weeds that are present, and, as the growing season progresses, herbicides with preemergent activity lose effectiveness. Thus, a few weeds are commonly present in an otherwise weed-free area surrounding the tree. Existing studies on pecan evaluated no vegetation control (Foshee et al., 1995; Norton and Storey, 1970; Patterson and Goff, 1994; Patterson et al., 1990), or control of only grass or dicot weeds (Foshee et al., 1997) compared with a weed-free control. However, studies on agronomic crops have demonstrated that relatively low weed densities can decrease yields (Klingaman and Oliver, 1994; Knezevic et al., 1994). Our objective was to evaluate the effects of a low weed population in close proximity to the tree on growth of pecan trees during orchard establishment.

We chose two weed species that commonly invade herbicide-treated areas in pecan

Received for publication 21 Dec. 1998. Accepted for publication $25 \mathrm{Feb}$. 1999. Approved for publication by the Oklahoma Agricultural Experiment Station. The cost of publishing this paper was defrayed in part by the payment of page charges. Under postal regulations, this paper therefore must be hereby marked advertisement solely to indicate this fact. orchards. These were cutleaf evening primrose, a cool-season annual (Stucky, 1981), and Palmer amaranth, a warm-season annual (Keeley et al., 1987). Seed of primrose germinate in autumn and the plant grows slowly as a prostrate rosette form until spring. Rapid growth then occurs, with flowering and seed production ending in June. Plants normally die as temperatures rise in late June or early July. Palmer amaranth germinates in late spring at about the same time that primrose matures. Additional amaranth seed germinate throughout summer, and plants continue to grow and produce seeds until killed by low temperatures in the fall. Together, these weeds present a temporal succession of weed interference commonly found in pecan orchards. Effects of these weeds and their density are examined in this study.

Table 1. The influence of one or two cutleaf evening primrose plants and one or two Palmer amaranth plants, alone or in succession, on trunk diameter and current-season's shoot growth of nonbearing seedling pecan trees.

\begin{tabular}{|c|c|c|c|c|c|c|c|c|}
\hline \multirow[b]{2}{*}{ Species } & \multirow{2}{*}{$\begin{array}{c}\text { No. of weeds } \\
\text { of each } \\
\text { species/tree }\end{array}$} & \multicolumn{3}{|c|}{ Trunk diam $(\mathrm{mm})$} & \multicolumn{4}{|c|}{ Total current-season growth $(\mathrm{cm})$} \\
\hline & & 1996 & 1997 & 1998 & 1996 & 1997 & 1998 & Cumulative \\
\hline None & 0 & 24 & 38 & 50 & 90 & 398 & 1154 & 1642 \\
\hline \multirow[t]{2}{*}{ Cutleaf evening primrose } & 1 & 23 & 34 & 44 & 60 & 310 & 754 & 1125 \\
\hline & 2 & 24 & 34 & 44 & 62 & 300 & 884 & 1245 \\
\hline \multirow[t]{2}{*}{ Palmer amaranth } & 1 & 22 & 31 & 40 & 69 & 250 & 832 & 1150 \\
\hline & 2 & 25 & 30 & 39 & 96 & 197 & 562 & 855 \\
\hline \multicolumn{9}{|l|}{ Cutleaf evening primrose } \\
\hline \multirow[t]{2}{*}{ + Palmer amaranth } & 1 & 19 & 27 & 34 & 49 & 189 & 559 & 798 \\
\hline & 2 & 20 & 24 & 26 & 43 & 98 & 211 & 351 \\
\hline \multicolumn{9}{|l|}{$\underline{\text { Contrasts }}$} \\
\hline None vs. weeds & & NS & ** & ** & $*$ & ** & ** & ** \\
\hline Primrose vs. amaranth & & NS & NS & NS & NS & NS & NS & NS \\
\hline One vs. two primrose & & NS & NS & NS & NS & NS & NS & NS \\
\hline One vs. two amaranth & & NS & NS & NS & NS & NS & NS & NS \\
\hline \multicolumn{9}{|l|}{ Single species } \\
\hline vs. succession & & * & $* *$ & ** & * & $* *$ & $* *$ & ** \\
\hline \multicolumn{9}{|l|}{ One-plant succession } \\
\hline vs. two-plant succession & & NS & NS & NS & NS & NS & NS & NS \\
\hline
\end{tabular}

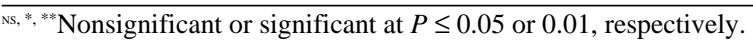

Bareroot seedling 'Apache' trees were planted during Feb. 1996 on a 3.1-m × 6.1-m spacing at the Pecan and Fruit Research Station near Perkins, Okla. The soil is a Teller sandy loam (fine-loamy, mixed, thermic Udic Argiustoll). Trees were 1.5 to $2 \mathrm{~m}$ tall with a single taproot $\approx 80 \mathrm{~cm}$ long. The taproot was pruned to $40 \mathrm{~cm}$ long and any damaged lateral roots were removed. The tops were pruned to $80 \mathrm{~cm}$. Trees were not pruned during the rest of the experiment. The trees were watered after transplanting, then three more times at 1to 2-week intervals. Watering was by hand, with each tree receiving $\approx 10 \mathrm{~L}$ of water per irrigation. Trees were fertilized annually in April and May according to Oklahoma Cooperative Extension Service recommendations (McCraw et al., 1994).

The area centered on the tree that was maintained weed-free, except for the designated weeds, was $11.2 \mathrm{~m}^{2}$. Treatments included a weed-free control and one or two plants of the weeds tested $30 \mathrm{~cm}$ from the trunk, or a succession of one or two plants of primrose followed by a like number of amaranth plants. If two primrose and/or amaranth plants were present, they were $180^{\circ}$ from each other, each $30 \mathrm{~cm}$ from the tree trunk. In Feb. 1996, primrose was transplanted from other sites. Amaranth was transplanted in June. During succeeding years, the appropriate number of volunteer primrose and/or amaranth were maintained in the same locations. All other vegetation was removed physically or hand-sprayed with the herbicide glyphosate [ $N$-(phosponomethyl)glycine].

Soil moisture was measured at two trees of each treatment with tensiometers placed 30 $\mathrm{cm}$ from the tree trunk and $30 \mathrm{~cm}$ deep. Data were recorded about three times per week during the growing season.

Trunk diameter was measured $30 \mathrm{~cm}$ above the soil surface while the trees were dormant each year. Total current-season's shoot growth 
was measured annually after leaf fall.

Treatments were arranged in a completely randomized design with nine single-tree replications per treatment. Data were analyzed by analysis of variance with treatment means compared using orthogonal contrasts.

\section{Results}

In 1996, trunk growth was suppressed more by a succession of primrose plants followed by amaranth plants than by primrose or amaranth plants alone (Table 1). In 1997 and 1998, all weed treatments suppressed trunk growth compared to the control. A succession of primrose followed by amaranth plants suppressed growth more than either species alone. Trunk growth suppression was similar whether there were one or two plants competing with the tree. Three years after transplanting, trunk diameter of trees with primrose plants averaged $15 \%$ smaller than the control, those with amaranth plants averaged $21 \%$ smaller, and those with a succession of primrose plants followed by amaranth plants averaged $40 \%$ smaller.

Current-season's shoot growth was suppressed during all 3 years of the study by weed competition (Table 1). There were no differences in growth suppression between primrose or amaranth plants, or between one or two plants competing with the tree. However, a succession of primrose plants followed by amaranth plants reduced current-season's shoot growth more than either weed species alone. The cumulative shoot growth reduction averaged $28 \%$ with primrose plants, $39 \%$ with amaranth plants, and $65 \%$ when primrose plants were followed by amaranth plants.

Soil moisture was monitored in all treatments. For simplicity, we present soil moisture data only for the weed-free control and the treatment with two primrose plants followed by two amaranth plants (Fig. 1). Soil moisture responses were similar whether the soil was maintained weed-free or had one or two primrose plants. Soil moisture responses were also similar for all treatments with amaranth plants. In 1996, soil moisture was slightly higher when trees were maintained weed-free than when primrose was followed by amaranth, except during 2 weeks in July when soil moisture was rapidly depleted if amaranth plants were present (Fig. 1). During this 2-week period, trees experienced substantially more water stress when amaranth plants were present than when the area was maintained weed-free. Primrose had produced seed and died by the time water stress was severe in July. Amaranth plants were actively growing during this period, and soil moisture data were similar for all treatments with amaranth. In 1997, the soil moisture pattern was very similar to 1996 , with a high moisture stress period in July if amaranth was present. However, other than for $\approx 10 \mathrm{~d}$ in July, soil moisture was similar whether amaranth was present or not. In 1998, rainfall was frequent until June, then abruptly ended, with little rainfall until September. Soil moisture was usually greater if weeds were absent, although there were some exceptions. During August and early September, soil mois-

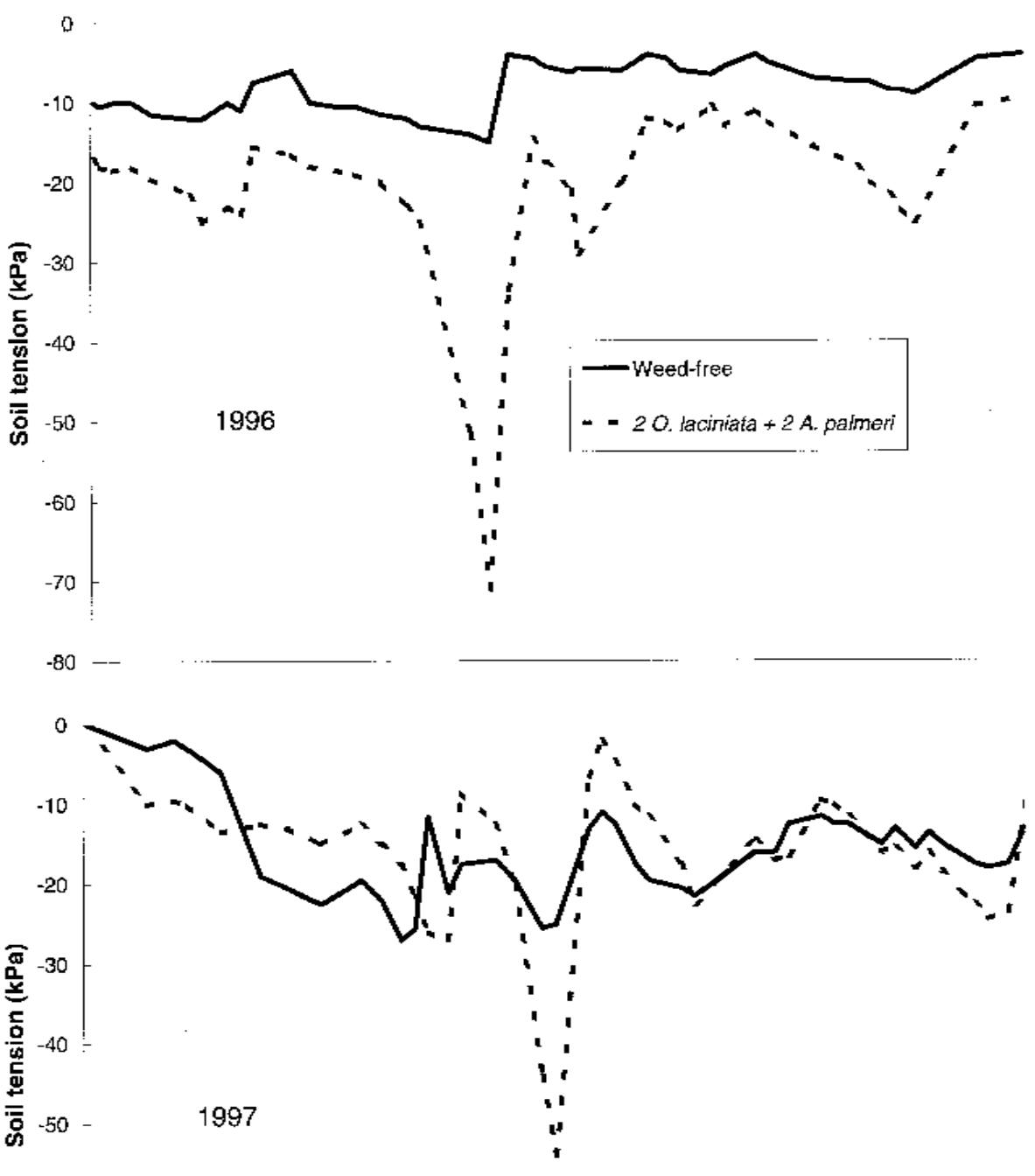

$-60$
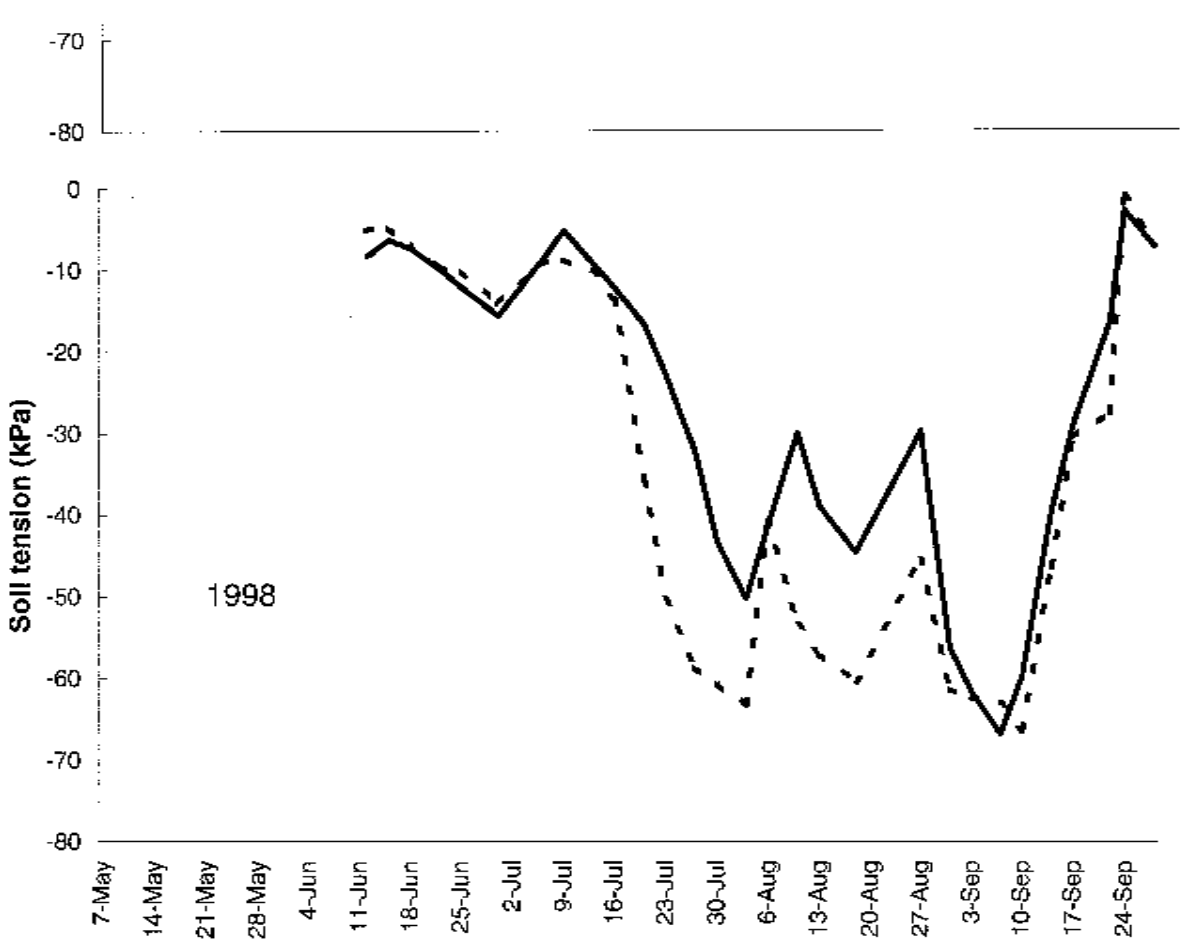

Fig. 1. The influence of two cutleaf evening primrose followed by two Palmer amaranth compared to the weed-free control on soil tension during the 3-year study. 
ture measurements indicated all trees with or without amaranth plants were under severe moisture stress.

\section{Discussion}

Tree growth was reduced if any weeds were competing with the tree (Table 1). A single primrose plant suppressed cumulative shoot growth by $31 \%$ and one amaranth plant by $30 \%$. An additive effect of the two weed species on growth suppression would have resulted in a $61 \%$ growth reduction when combined, which compares favorably with the $51 \%$ reduction we found using a succession of one plant of each species. When the number of weeds was increased to two of each species, the growth reductions were $24 \%$ and $48 \%$ for primrose and amaranth, respectively. Additive effects of the two species would yield $72 \%$ growth suppression. We observed a $79 \%$ reduction in cumulative shoot growth, suggesting that their effects were indeed additive.

Weeds may compete for water, thus reducing tree growth. However, the differences in soil moisture among treatments seem insufficient to account for the growth reduction observed (Fig. 1). Weeds also compete for nutrients (Goff et al., 1991), a condition that can also reduce growth. However, that nutrient shortage alone could account for the growth reduction is unlikely, since trees were well fertilized using a split application, and elements were within normal sufficiency ranges (data not shown). Palmer amaranth has a negative allelopathic effect on growth of several species (Menges, 1988). The combined effects of competition and allelopathy, termed interference (Muller, 1969), are probably responsible for the reduction in growth of pecan trees.

Other studies have documented the necessity of weed control to enhance growth (Foshee et al., 1995; Norton and Storey, 1970; Patterson and Goff, 1994; Patterson et al., 1990) and improve production (Foshee et al., 1997) of pecan. However, none have demonstrated that a low weed density in close proximity to the tree is detrimental. Our data conclusively demonstrate that a low density of cutleaf evening primrose or Palmer amaranth substantially suppresses growth of young pecan trees, and that the effects of these two weed species are additive when Palmer amaranth follows cutleaf evening primrose. Although these data do not conclusively demonstrate a negative allelopathic interaction among the weeds tested and pecan, allelopathy is suggested.

\section{Literature Cited}

Aitken, J.B. 1974. Influence of glyphosate on grasses in peaches and pecans. Proc. Southern Weed Sci. Soc. 27:170-175.

Arnold, C.E. and J.H. Aldrich. 1979. Weed control in immature pecan (Carya illinoensis) and peach (Prunus persica) plantings. Weed Sci. 27:638641.

Foshee, W.G., W.D. Goff, M.G. Patterson, and D.M. Ball. 1995. Orchard floor crops reduce growth of young pecan trees. HortScience 30:979-980.

Foshee, W.G., III, R.W. Goodman, M.G. Patterson, W.D. Goff, and W.A. Dozier, Jr. 1997. Weed control increases yield and economic returns from young 'Desirable' pecan trees. J. Amer. Soc. Hort. Sci. 122:588-593.

Goff, William D., M.G. Patterson, and M.S. West.
1991. Orchard floor management practices influence elemental concentrations in young pecan trees. HortScience 26:1379-1381.

Hunter, J.H. 1950. Some interrelationships of cultural practices, fertilization, and the production of quality pecan nuts. Proc. Southeastern Pecan Growers' Assn. 43:78-86.

Keeley, P.E., C.H. Carter, and R.J. Tullen. 1987. Influence of planting date on growth of Palmer amaranth (Amaranthus palmeri). Weed Sci. 35:199-204.

Klingaman, T.E. and L.R. Oliver. 1994. Palmer amaranth (Amaranthus palmeri) interference in soybeans (Glycine max). Weed Sci. 42:523527.

Knezevic, S.Z., S.F. Weise, and C.J. Swanton. 1994. Interference of redroot pigweed (Amaranthus retroflexus) in corn (Zea mays). Weed Sci. 42:568-576.

McCraw, B.D., G.V. Johnson, and M.W. Smith. 1994. Fertilizing pecan and fruit trees. Okla. Coop. Ext. Serv. F-6232.

Menges, R.M. 1988. Allelopathic effects of Palmer amaranth (Amaranthus palmeri) on seedling growth. Weed Sci. 36:352-328.

Muller, C.H. 1969. Allelopathy as a factor in ecological process. Vegetation 18:348-357.

Norton, J.A. and J.B. Storey. 1970. Effect of herbicides on weed control and growth of pecan trees. Weed Sci. 18:522-524.

Patterson, M.G. and W.D. Goff. 1994. Effects of weed control and irrigation on pecan (Carya illinoinensis) growth and yield. Weed Tech. 8:717-719.

Patterson, M.G., G. Wehtje, and W.D. Goff. 1990. Effects of weed control and irrigation on the growth of young pecans. Weed Tech. 4:892894.

Stucky, J.M. 1981. Identifying seedling and mature weeds common in the southeastern United States. North Carolina Agr. Res. Serv. and North Carolina Agr. Ext. Serv., Raleigh. 